\title{
Pollutants in Plastics within the North Pacific Subtropical Gyre
}

Qiqing Chen, ${ }^{\dagger, \ddagger, \S}$ Julia Reisser, ${ }^{*}, \oplus$ Serena Cunsolo, ${ }^{\dagger, \|}$ Christiaan Kwadijk, ${ }^{\perp}$ Michiel Kotterman, ${ }^{\perp}$ Maira Proietti, ${ }^{\#}$ Boyan Slat, ${ }^{\dagger}$ Francesco F. Ferrari, ${ }^{\dagger}$ Anna Schwarz, ${ }^{\dagger}$ Aurore Levivier, ${ }^{\dagger}$ Daqiang Yin, ${ }^{\nabla}$ Henner Hollert, ${ }^{\ddagger}$ and Albert A. Koelmans ${ }^{\perp, O_{\odot}}$

${ }^{\dagger}$ The Ocean Cleanup Foundation, Martinus Nijhofflaan 2, 2624 ES Delft, The Netherlands

${ }^{\ddagger}$ Department of Ecosystem Analysis, Institute for Environmental Research, ABBt - Aachen Biology and Biotechnology, RWTH Aachen University, 1 Worringerweg, 52074 Aachen, Germany

${ }^{\S}$ State Key Laboratory of Estuarine and Coastal Research, East China Normal University, 3663 Zhongshan N. Road, 200062 Shanghai, P.R. China

"School of Civil Engineering and Surveying, Faculty of Technology, University of Portsmouth, Portland Building, Portland Street, Portsmouth, PO1 3AH, United Kingdom

${ }^{\perp}$ Wageningen Marine Research, Wageningen University \& Research, P.O. Box 68, 1970 AB IJmuiden, The Netherlands

\#Instituto de Oceanografia, Universidade Federal do Rio Grande, Rio Grande, Brazil

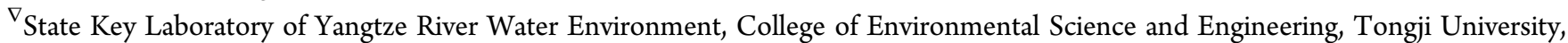
1239 Siping Road, 200092 Shanghai, P.R. China

OAquatic Ecology and Water Quality Management Group, Department of Environmental Sciences, Wageningen University \& Research, P.O. Box 47, 6700 AA Wageningen, The Netherlands

\section{Supporting Information}

ABSTRACT: Here we report concentrations of pollutants in floating plastics from the North Pacific accumulation zone (NPAC). We compared chemical concentrations in plastics of different types and sizes, assessed ocean plastic potential risks using sediment quality criteria, and discussed the implications of our findings for bioaccumulation. Our results suggest that at least a fraction of the NPAC plastics is not in equilibrium with the surrounding seawater. For instance, "hard plastic" samples had significantly higher PBDE concentrations than "nets and ropes" samples, and $29 \%$ of them had PBDE composition similar to a widely used flame-retardant mixture. Our findings indicate that NPAC plastics may pose a chemical risk to organisms as $84 \%$ of the samples had at least one chemical exceeding sediment threshold effect levels. Furthermore, our surface trawls collected more plastic than biomass (180 times on average), indicating that some NPAC organisms feeding upon floating particles may have plastic as a major component of their diets. If gradients for pollutant transfer from NPAC plastic to predators exist (as indicated by our fugacity ratio calculations), plastics may play a role in transferring chemicals to certain marine organisms.
Unprocessed sea surface sample from the North Pacific subtropical gyre

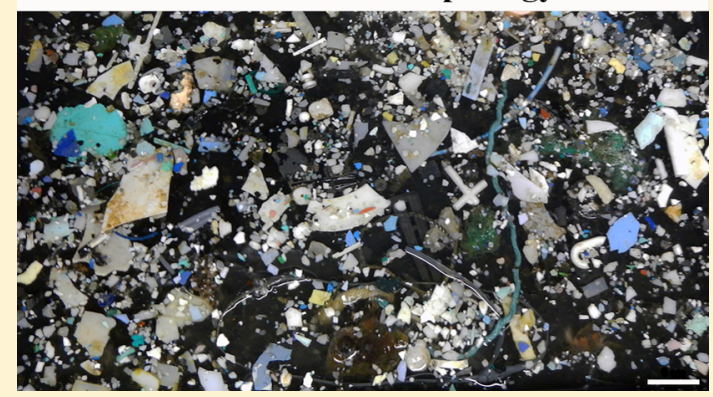

\section{INTRODUCTION}

Plastics are widely distributed in the world's oceans, with some buoyant plastics accumulating within subtropical gyres. ${ }^{1}$ Persistent bioaccumulative toxic (PBT) chemicals such as polycyclic aromatic hydrocarbons (PAHs), polychlorinated biphenyls (PCBs), polybrominated diphenyl ethers (PBDEs), and nonylphenol (NP) detected on these human-made ocean particles have raised concerns with respect to marine environmental health. ${ }^{2-6}$ PBTs can associate with ocean plastics via two main routes: direct addition to plastics for flame retardation and other purposes, and sorption to plastics from the marine environment through partitioning mechanisms. ${ }^{7,8}$ Even though some PBTs have been banned for 
pollution. Common floating oceanic plastics include hard plastics (wall thickness $>1 \mathrm{~mm}$ ) used in packaging (e.g., bottle caps) and fishing (e.g., buoys), fibrous ropes used by maritime industries, fishing nets, and preproduction pellets. ${ }^{1}$ All of these fragment into progressively smaller pieces through abrasion, UV photo-oxidation, and biodegradation, with an increase in the risk of ingestion by different marine species as the plastic fragment size decreases. ${ }^{11,12}$ Additionally, smaller particles possess a larger surface to volume ratio and shorter intrapolymer diffusion path lengths, which under nonequilibrium conditions can lead to a dependence of PBT concentrations on particle size. ${ }^{13}$

It is well-known that PBTs can be found in plastics contaminating the environment, ${ }^{14}$ but the environmental chemistry and toxicological hazard of ocean plastic-associated chemicals are still poorly understood. ${ }^{13,15}$ Furthermore, no risk assessment for such pollutants is available. Assuming that plastic-bound and sediment organic matter-bound PBTs have similar partition coefficients, ${ }^{15,16}$ desorption half-lives ${ }^{15}$ and exposure pathways, ${ }^{13,15}$ we suggest the application of standards for the environmental quality of sediments ${ }^{17-19}$ to assess prospective risks of plastic-bound PBTs to marine biota. ${ }^{20}$

Here we report concentrations of 15 PAH congeners, 28 PCB congeners, 15 PBDE congeners, and HBCD in plastics from the North Pacific accumulation zone (NPAC). This is a major oceanic hotspot for floating debris formed within the North Pacific subtropical gyre, ${ }^{21,22}$ between California and Hawaii. The NPAC is also known as "The Great Pacific Garbage Patch" or "Eastern Garbage Patch". 5,23,24 We used our measurements to investigate the effect of plastic particle type and size on PBTs concentrations and assess the prospective risks of oceanic plastic-bound PBTs to pelagic biota by using environmental quality criteria for sediments. ${ }^{17-19,25}$ Furthermore, we discuss some of the possible bioaccumulation implications of our findings, using plastic/biomass ratios measured in this study and NPAC biota data from the literature.

\section{MATERIALS AND METHODS}

Sampling. In August 2015, we sampled buoyant plastics within surface waters of the NPAC, while aboard the RV Ocean Starr (Figure 1). At each sampling station, we deployed four surface trawls simultaneously for around $2.5 \mathrm{~h}$ at 2 knots ground speed. Particles larger than $500 \mu \mathrm{m}$ were collected by single-use cod-ends fitted onto two Manta Trawls $(90 \times 15 \mathrm{~cm}$ mouth) deployed by the sides of the vessel. After each towing event, the nets were thoroughly washed with seawater and the detached cod-ends were placed inside zip-lock bags that were then frozen at $-2{ }^{\circ} \mathrm{C}$ for transport to the laboratory. To increase sampling effort toward larger debris, two large Neuston trawls ("Mega Trawls", $6 \times 1.5 \mathrm{~m}$ mouth) with a $1.5 \mathrm{~cm}$ mesh were also deployed at the rear of the vessel. The cod-ends of the Mega Trawls were opened into large fishing crates filled with seawater to separate the plastics from marine life, as well as to keep organisms alive before release. Buoyant debris captured by Mega Trawls were picked up from the crates, wrapped in aluminum, and frozen at $-2{ }^{\circ} \mathrm{C}$ for transport to the laboratory.

Sorting. Manta and Mega trawl samples from nine sampling stations were prepared for PBTs analyses, with the plastics from neighboring locations being pooled together into three sets of samples (Figure 1). Each trawl sample was defrosted at room temperature and washed with filtered fresh water into five sieves that separated the material into the following mesh sizes:

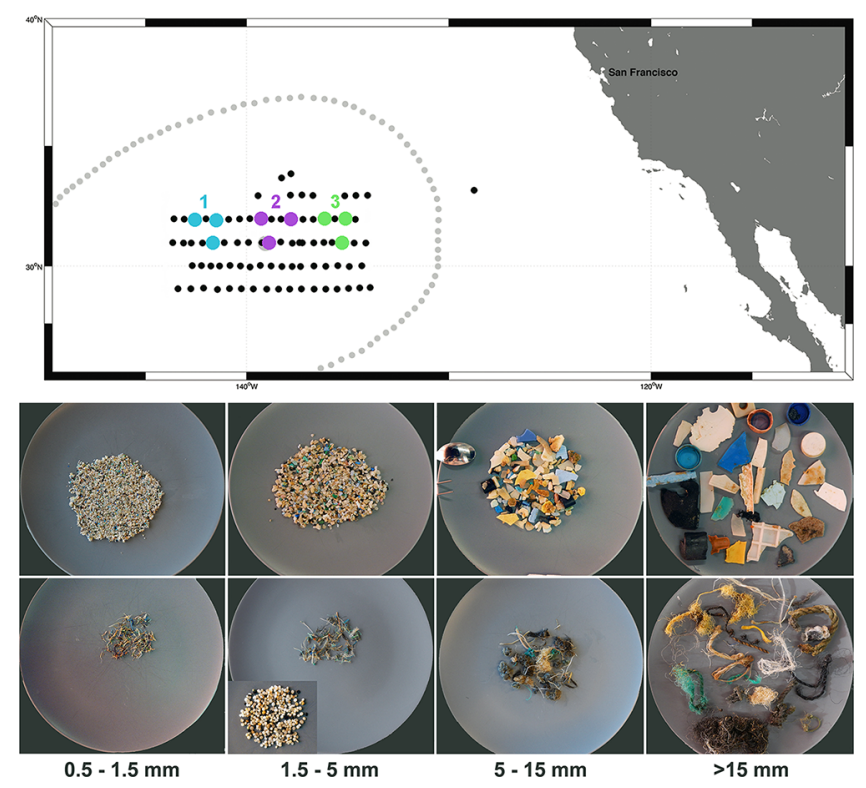

Figure 1. Sampling region and types of plastic analyzed in this study. In the map, black dots show all locations sampled by RV Ocean Starr (paired Manta and Neuston net tows); gray dots indicate limits of the 'North Pacific accumulation zone', as predicted by Maximenko et al. 2011 ; $^{21}$ colored dots show sampling stations whose samples were used for the pollutant analyses reported in this study, with the color indicating which stations had its net tow samples pooled for analysis. Photographs show examples of samples analyzed by this study, with top row containing "hard plastic" samples and bottom row showing "nets and ropes" samples. A "pellet" sample is also shown as a small insertion in the bottom row (size $1.5-5 \mathrm{~mm}$ ).

(1) $0.05-0.15 \mathrm{~cm},(2) 0.15-0.5 \mathrm{~cm},(3) 0.5-1.5 \mathrm{~cm},(4) 1.5-5$ $\mathrm{cm}$, and $>5 \mathrm{~cm}$. The items $>5 \mathrm{~cm}$ collected by the top sieve were then sorted by length into additional size classes: (5) 5$10 \mathrm{~cm}$, (6) $10-50 \mathrm{~cm}$, and (7) $>50 \mathrm{~cm}$. Only Manta Trawl samples were considered for the smallest size ranges (0.05$0.15 \mathrm{~cm}, 0.15-0.5 \mathrm{~cm}$, and $0.5-1.5 \mathrm{~cm}$ ), whereas for items larger than $1.5 \mathrm{~cm}$, samples from both Manta and Mega trawls were considered. To separate the floating material (e.g., plastic) from biomass, we placed the sized materials into metallic containers filled with cold filtered seawater (salinity $=3.5 \%$ ). We then picked up the floating plastics with forceps, and counted and separated them into the following types: (1) "hard plastics", fragments and objects made of plastic with thick walls ( 1-3 mm) and low flexibility; (2) "nets and ropes", pieces of ropes and fishing nets made of plastic fibers; and (3) "pellets", preproduction plastic nurdles in the shape of a cylinder, disk or sphere (Figure 1). Rare floating debris that did not fall into these categories (e.g., foam, rubber, wood) were not considered in this study. In order to decrease the mass for the three largest size classes $(5-10 \mathrm{~cm}, 10-50 \mathrm{~cm}$, and $>50 \mathrm{~cm})$ used for PBTs extraction, while keeping the number of particles within each pooled sample, we randomly cut three pieces of approximately $1.5 \mathrm{~cm}^{2}$ out of these objects. The remainder of this debris was not used in this study. Each sample resulting from the process described above was then cleaned (i.e., manual removal of biofouling), placed in preweighed aluminum foil and weighed in a high precision scale (EX324M, OHAUS Explorer, New Jersey). Samples with a wet weight of more than $100 \mathrm{~g}$ were subsampled such that all samples $(\mathrm{N}=45)$ used for the extraction of PBTs had a wet weight of less than $100 \mathrm{~g}$. 
Polymer Identification. In order to determine which polymers predominate in our samples, we randomly took 8-10 pieces within each of our plastic type/size categories (146 samples in total) and performed Fourier Transform Infrared Spectrometry (FT-IR Spectrum 100, PerkinElmer, equipped with the Universal ATR accessory). Polymer type was determined by comparing sample FT-IR spectra against known standard polymer spectra from the ATR polymer library (Spectrum Search Plus Software, PerkinElmer).

PBTs Quantification. The PBTs in our ocean plastic samples were Soxhlet extracted, and analyzed using High Performance Liquid Chromatography (HPLC) for PAHs and Gas Chromatography-Mass Spectrometry (GC-MS) for PCBs, PBDEs, and HBCD. We measured chemical concentrations $(\mu \mathrm{g}$ per $\mathrm{kg}$ of plastic dry weight) of $15 \mathrm{PAH}$ congenersnaphthalene, acenaphthene, fluorene, phenanthrene, anthracene, fluoranthene, pyrene, benzo[a] anthracene, chrysene, benzo[e]pyrene, benzo[b]fluoranthene, benzo[k]fluoranthene, benzo[a]pyrene, dibenzo[a.h] anthracene, benzo[ghi]perylene; 28 PCB congeners - CB-28, CB-31, CB-47, CB-49, CB-52, CB-56, CB-66, CB-85, CB-87, CB-97, CB-101, CB-105, CB110, CB-118, CB-128, CB-137, CB-138, CB-141, CB-149, CB151, CB-153, CB-156, CB-170, CB-180, CB-187, CB-194, CB202, CB-206; 15 PBDE congeners - BDE-28, BDE-47, BDE49, BDE-66, BDE-71, BDE-75, BDE-85, BDE-99, BDE-100, BDE-119, BDE-138, BDE-153, BDE-154 (determined as BDE$154+$ BB-153), BDE-183, BDE-190; and a combination of $\alpha$ $\mathrm{HBCD}, \beta-\mathrm{HBCD}$, and $\gamma$-HBCD (reported as "HBCD" hereafter). Procedural and plastic blanks were prepared and tested during analysis. The limit of quantification (LOQ) for benzo(e)pyrene in plastics was $1.04 \mu \mathrm{g} / \mathrm{kg}$, and $0.71 \mu \mathrm{g} / \mathrm{kg}$ for all other PAHs. The LOQ values for PCB congeners, PBDE congeners, and $\mathrm{HBCD}$ in plastics were $0.16 \mu \mathrm{g} / \mathrm{kg}, 0.10 \mu \mathrm{g} / \mathrm{kg}$, and $0.44 \mu \mathrm{g} / \mathrm{kg}$, respectively. Satisfactory recoveries (70$120 \%)$ and intraday and interday precisions $(<15 \%)$ were obtained for all tested contaminants. All PBTs extractions and clean up procedures were conducted according to the accredited standard procedures of the Wageningen Marine Research (The Netherlands). They are described in detail in the Supporting Information (SI).

PBT concentrations below the detection limit were replaced by half of the detection limit, ${ }^{26}$ except for two cases. First, we did not consider values coming from samples with dry mass $<100 \mathrm{mg}$, as their PBT detection limits were very high. This was the case for two samples, both within type "nets and ropes" and size class $0.05-0.15 \mathrm{~cm}$. Second, when the half detection limit value of a sample exceeded the lowest measured concentration for a certain chemical, we replaced them by "not detected" (nd). All PBT concentration values obtained in this study, both before and after applying the changes described above, can be found in Figshare. ${ }^{27}$ Principle Component Analysis (PCA) was performed to reduce the dimensionality of the $\mathrm{PCB}$ or PDBE congeners data. PBT concentration differences among plastic types and sizes were evaluated by a multivariate nonparametric rank test (data were not normally distributed in the Kolmogorov-Smirnov test) with $p<0.05$ indicating significant differences.

Effect Assessment. We compared PBT concentrations reported here with threshold effect levels (TEL) - levels below which adverse effects are not expected to occur - and with probable effect levels (PEL) - levels above which adverse effects are expected to occur more often than not-as reported in the Canadian Environmental Quality Standards (EQS) for PBTs in sediment. ${ }^{17-19,25}$ Both TEL and PEL values were available for PAHs (naphthalene, acenaphthene, fluorene, phenanthrene, anthracene, fluoranthene, pyrene, benzo[a]anthracene, chrysene, benzo[a]pyrene, dibenzo[a,h] anthracene), and total PCBs, whereas only TEL values were available for PBDEs (tri-BDE, tetra-BDE, penta-BDE, hexa-BDE, BDE-99, and BDE-100) and $\mathrm{HBCD}$. These EQS values and plastic-bound PBT concentrations were compared as a first tier in the risk assessment of priority chemicals we identified in NPAC plastics.

PBT Concentrations in Ocean Plastics and Marine Sediments. To contextualize the PBT concentrations measured here, we compared our values with those found in ocean plastics and marine sediments worldwide (SI Table S1). We compared plastic and sediment PBT concentrations since differences between PBT levels in these two types of particles may be indicative of the relative affinity and risk of PBTs residing in plastic when compared to those in sediment. We selected 16 key PBTs with a high reported frequency (>75\%) among the four ${ }^{2,3,20,28}$ ocean plastic and $29^{29-57}$ marine sediment studies we found. Since plastics can be seen as almost $100 \%$ organic, whereas sediments contain only a fraction of organic matter (OM) ${ }^{16}$ we also compared plastic-associated PBT concentrations with OM-normalized PBT concentrations in sediments using data from studies that provided OM\% for sediment $\left(16^{29,30,35,39-41,43-47,50,52,53,55,56}\right.$ out of the 29 marine sediment papers $\left.{ }^{29-57}\right)$. All sediment and plastic data used in this study are available in Figshare. ${ }^{27}$

Bioaccumulation Inferences. It has been suggested that plastic can act as a significant carrier of PBTs to marine animals if (1) plastic is a major component of the diet, and (2) PBT fugacities in ingested plastic are higher than those in the animals' lipids. ${ }^{13}$ Following recent examples, ${ }^{58,59}$ we explore these conditions for the present case using information from this study as well data from previous NPAC research.

It is well-known that prey availability influences the diet of predators, with the relative abundance of different prey items being a good predictor of the diet of opportunistic feeders. ${ }^{60,61}$ As such, we calculated plastic mass to biomass ratios using the contents collected by our Manta trawls (500 $\mu \mathrm{m}$ mesh). These ratios may be good predictors of relative amounts of plastic available to and potentially ingested by opportunistic surface feeders whose prey size is larger than $0.5 \mathrm{~mm}$. Wet weight of the biomass collected by each Manta net tow was determined and, since we kept these biomass samples frozen for future analyses, its dry weight was assessed using wet/dry weight ratios from our other NPAC Manta net tows (see black dots in the map of Figure 1). Both plastic/biota (using all material collected), and microplastic/zooplankton (using 0.5-5 mm particles only) ratios were calculated. We computed these plastic/biota ratios using all Manta net tows used in this study $(N=18)$, as well as separated by the time of sampling: daytime $(N=8)$ and nighttime $(N=10)$. Weights of biota and plastic collected by each net tow of this study are available in Figshare. $^{27}$

We also calculated fugacity ratios between some predators (yellowtail fish ${ }^{62}$ and Laysan albatross ${ }^{63}$ captured within the North Pacific subtropical gyre) and putative ingested plastic (our plastic samples). Fugacity ratios (F1/F2) were determined by estimating equilibrium aqueous $\mathrm{PBT}$ concentrations in plastic (F1; from averaged chemical concentrations in our plastic samples, and partition coefficients for polyethylene), ${ }^{8}$ and equilibrium aqueous PBT concentrations in lipid of NPAC predators $(\mathrm{F} 2$; from averaged chemical concentrations in 
Table 1. PBT Concentrations in the Plastic Samples Analyzed in This Study ${ }^{a}$

\begin{tabular}{|c|c|c|c|c|c|}
\hline plastic type & plastic size $(\mathrm{cm})$ & $\sum \mathrm{PAHs}(\mu \mathrm{g} / \mathrm{kg})$ & $\sum \mathrm{PCBs}(\mu \mathrm{g} / \mathrm{kg})$ & $\sum$ PBDEs $(\mu \mathrm{g} / \mathrm{kg})$ & $\mathrm{HBCD}(\mu \mathrm{g} / \mathrm{kg})$ \\
\hline \multirow[t]{7}{*}{ hard plastics } & $0.05-0.15$ & $14.4-29.2$ & $19.3-37.5$ & $6.8-49.5^{*}$ & $21-160$ \\
\hline & $0.15-0.5$ & $34.4-202.6^{*}$ & $12.1-81$ & $5.1-32.3$ & $3.1-76$ \\
\hline & $0.5-1.5$ & $96.6-801.6^{*}$ & $4.6-78.7^{*}$ & $5-187.7 *$ & $0.03-740$ \\
\hline & $1.5-5$ & $34.8-64.2$ & $2.2-137.5 *$ & $6.1-18.2$ & $0.01-0.9$ \\
\hline & $5-10$ & $117.4-227.5$ & $12.6-16$ & $2.6-46^{*}$ & $0.02-2.7$ \\
\hline & $10-50$ & $54.5-396.7 *$ & $9.9-135^{*}$ & $23.4-49.9$ & $0.01-1.5$ \\
\hline & $>50$ & $185.9-847.7$ & $2.8-93.1^{*}$ & $0.7-46.5$ & $0.02-4.3$ \\
\hline \multirow[t]{7}{*}{ nets and ropes } & $0.05-0.15$ & 1.5 & 9.1 & nd & nd \\
\hline & $0.15-0.5$ & $1.2-193860$ & $6.5-9.8$ & nd & nd \\
\hline & $0.5-1.5$ & $2.8-387.9$ & $2.7-5.8^{*}$ & $0.6-1.3$ & nd -1.8 \\
\hline & $1.5-5$ & $118.2-7236.1$ & $94.2-308.4^{*}$ & $0.6-4.3$ & $0.04-1.8$ \\
\hline & $5-10$ & $9.5-142.6$ & $0.7-4^{*}$ & $1.6-2.6$ & $0.04-0.1$ \\
\hline & $10-50$ & $133.7-284.5$ & $1.6-455.1^{*}$ & $11.4-52.1$ & $0.05-5.7$ \\
\hline & $>50$ & $46.3-680.5$ & $0.8-41.7 *$ & $3.4-6.1$ & $0.03-1.9$ \\
\hline pellets & $0.15-0.5$ & $61.7-101.6$ & $1.6-8.1^{*}$ & $5.4-66.1$ & $2-13$ \\
\hline
\end{tabular}

${ }^{a}$ Concentration ranges are shown separately for all the plastic type/size categories, which had three samples each (sampling locations 1 , 2, and 3 in Figure 1). The exception is type "nets and ropes", size class $0.05-0.15 \mathrm{~cm}$, which only had one sample. Values in bold indicate the occurrence of samples that exceed TEL values, and values in italic bold shows samples that exceed PEL values. PBDEs cells with an * indicates the presence of at least one sample with PBDEs composition similar to the flame retardant mixture formula Penta-BDE; ${ }^{74}$ PCBs cells with an * indicates the presence of at least one sample with PCBs composition similar to the commercial plasticizer Aroclor $1254 ;{ }^{99}$ and PAHs cells with an * indicates the presence of a sample with PAHs dominated by low molecular weight PAHs (LPAH).

Yellowtail fish's and Laysan albatross's lipids, ${ }^{62,63}$ and partition coefficients for lipid). ${ }^{8}$ F1/F2 higher than one indicates chemical transfer from ingested plastic to predator, while F1/ F2 lower than one suggests the opposite (chemical transfer from predator to ingested plastic). We calculated these putative fugacity ratios for all chemicals measured in both plastic and predator samples (fish and/or bird lipids), and with known polyethylene-water equilibrium partitioning constants $\left(K_{\mathrm{PE}}\right)$ and octanol-water equilibrium partitioning constants $\left(K_{\mathrm{OW}}\right)$. Even though our samples were not made of pure polyethylene, we have chosen to use $K_{\mathrm{PE}}$ in our calculations because (1) our FT-IR analysis suggests that polyethylene is the most common NPAC polymer (see results below), and (2) $K_{\mathrm{PE}}$ values are relatively high, making our F1/F2 calculations conservative (e.g., if we used partition coefficients for polypropylene, estimated F1/F2 would be higher).

\section{RESULTS AND DISCUSSION}

PBTs in NPAC Plastics. We detected PAHs, PCBs, PBDEs, and $\mathrm{HBCD}$ in most samples, with concentrations ranging from $1.2-193,860 \mu \mathrm{g} / \mathrm{kg}, 0.7-455 \mu \mathrm{g} / \mathrm{kg}, 0.6-188 \mu \mathrm{g} / \mathrm{kg}$, and 0.01-740 $\mu \mathrm{g} / \mathrm{kg}$, respectively (Table 1, SI Table S2). All plastics analyzed by FT-IR were identified as being made of polyethylene ( $71 \%$ ) or polypropylene (29\%; SI Figure S1). The dominance of these polymers in NPAC waters is likely due to both their high production rates and lower-than-seawater densities. $^{64}$ Both polymers have relatively high sorption coefficients for hydrophobic chemicals, ${ }^{7}$ with some studies reporting higher sorption of chemicals for polyethylene than polypropylene. ${ }^{14,65,66}$

We found that $84 \%(36 / 43)$ of our NPAC plastic samples had at least one chemical with concentrations exceeding the threshold effect levels considered. This indicates that NPAC plastics may pose a chemical risk to organisms that ingest them. Around $70 \%$ (30/43), 33\% (14/43), and 30\% (13/43) of the samples exceeded TEL values for PBDEs, PCBs, and PAHs, respectively. For PEL values, 9\% (4/43) and 5\% (2/43) exceeded thresholds for PAHs and PCBs, respectively (Table 1, SI Tables S3, S4 and S5).

Levels of plastic-associated PAHs, PCBs, and PBDEs showed no clear pattern with changes in particle size (Figure 2), which could be due to high variability in our data and/or having most of the plastic particles in equilibrium with their surrounding environment. ${ }^{7,67,68}$ The linear free energy relationship (LFER) model explains the partitioning of PBTs between seawater and plastics, ${ }^{69}$ and describes the free energy changes due to the chemical molecular interactions with both water and bulk sorbent phase without size-related parameters. ${ }^{70}$ The exception here was HBCD, which had significantly different concentrations between size classes (nonparametric rank comparison, $p=0.014)$, with HBCD concentrations being inversely proportional to plastic size. $\mathrm{HBCD}$ is a worldwide-used flame retardant additive, ${ }^{71,72}$ mostly used in polystyrenes $(0.7-2.5 \%$ HBCD $w / w$ embedded). ${ }^{73}$ As such, their relatively high concentrations in some microplastic samples could be due to the occurrence of microplastic particles that still contain HBCD additives. Alternatively, NPAC waters may have relatively high HBCD concentration (e.g., due to the occurrence of floating foams in the region) and only some particles within the small size classes have reached equilibrium.

Our findings suggest that not all NPAC plastics have their chemical burdens in equilibrium with the surrounding environment. For instance, PBDEs had their concentrations significantly higher $(p=0.002)$ in "hard plastics" $(32 \mu \mathrm{g} / \mathrm{kg} \mathrm{dw})$ than in "nets and ropes" samples (7 $\mu \mathrm{g} / \mathrm{kg}$; Figure 2). Moreover, $29 \%(6 / 21)$ of the "hard plastic" samples had PBDE composition similar to a widely used flame-retardant mixture: the DE-71 formulation $(r>0.75, p<0.05)$ (Table 1, SI Table S5). ${ }^{74}$ Based on these results, we suggest that at least a few "hard plastic" particles, with their relatively thick walls, may still have PBDE additives leaching out to the surrounding environment. Additionally, PCB congener patterns of $42 \%$ 


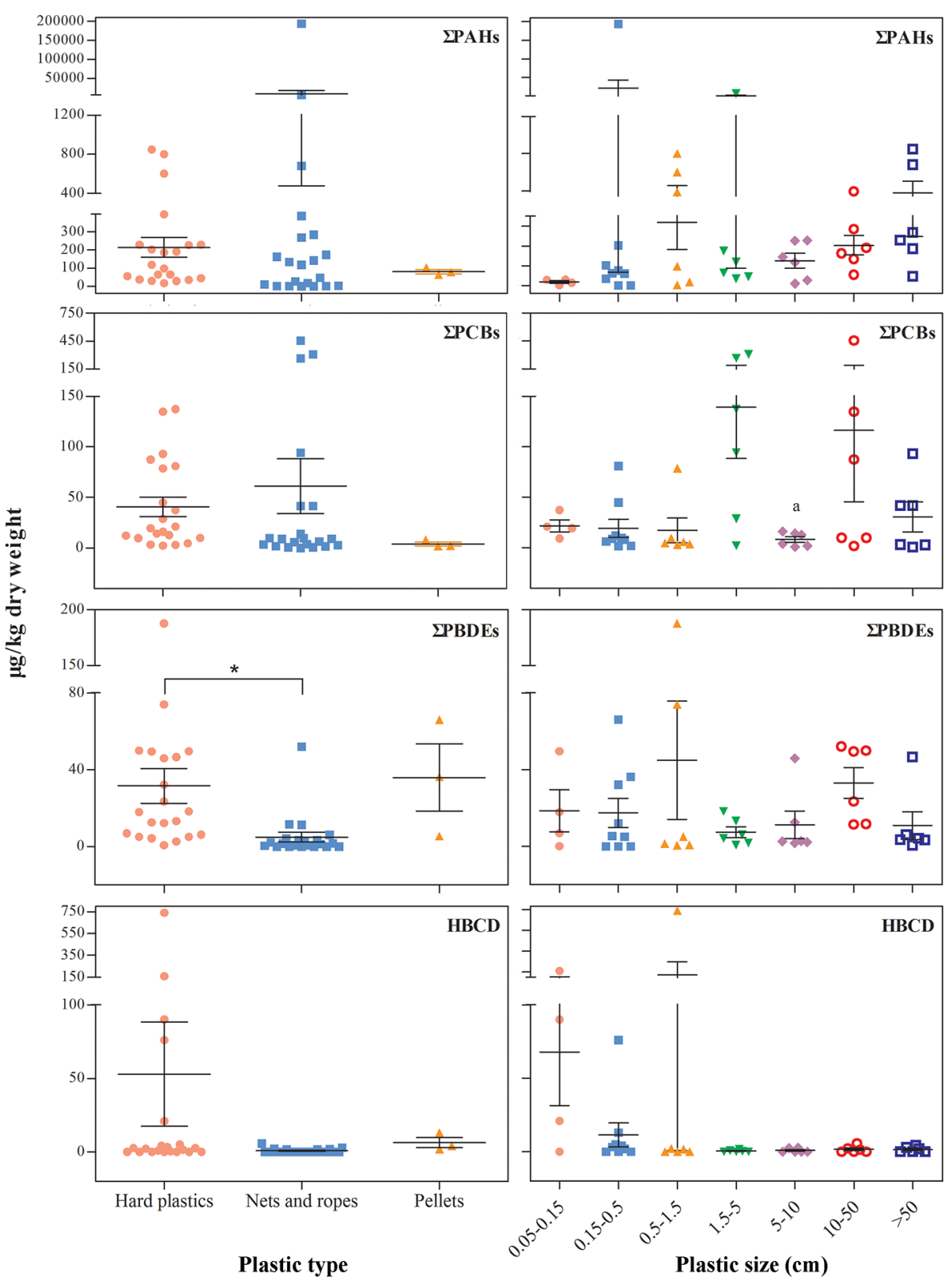

Figure 2. PBT concentrations in the ocean plastic samples of this study. Data points are displayed by plastic types (left column) and size classes (right column). Whiskers represent standard error ranges and middle lines are the mean values for each group. $*$ indicates significant difference $(p<$ 0.05 ) between two groups.

(18/43) of our plastic samples were similar to those of Aroclor 1254 additive $(r>0.75, p<0.05)$ (Table 1 , SI Table S4). As PCB production was banned in most countries in the 1970$80 \mathrm{~s},{ }^{5,75}$ the relatively high $\mathrm{PCB}$ concentrations in these oceanic plastics may be attributed to PCB legacy pollution (e.g., through sorption from water $)^{2,76,77}$ and/or illegal use of PCB additives in some modern plastics.

All samples considered in this study had detectable amounts of PAHs. Out of the $11 \mathrm{PAH}$ congeners with available effect threshold values, nine and eight had at least one sample with values exceeding their TEL and PEL values, respectively (SI Table S3). Most samples had more high molecular PAHs (HPAH) than low molecular PAHs (LPAH; SI Table S3). Such HPAH dominance remained even after excluding samples with possible PAHs degradation (LPAH/HPAH $<0.2) .{ }^{78}$ This indicates that NPAC plastics may have PAHs mostly from pyrogenic sources, ${ }^{78}$ which corroborates with a previous study. ${ }^{5}$ Nonetheless, the LPAH/HPAH ratio was found to be significantly different between "hard plastics" and "nets and ropes" samples (SI Figure S2). Three "hard plastic" samples had the LPAH/HPAH ratio higher than two (see SI Table S3), indicating that they may have PAHs dominated by petrogenic sources. $^{78}$

PCBs and PBDEs were detected in most ocean plastic samples analyzed. Two and 14 samples had their PCB concentrations respectively exceeding the PEL and TEL thresholds (SI Table S4). For PBDEs, 30 samples had concentrations above TEL values (SI Table S5). PEL thresholds for PBDEs were not available in the EQS used. PCB and PBDE congener concentrations were analyzed by PCA. PCBs were reconstituted to four principal components, which explained $89 \%$ of the total variance (SI Table S6). PC1, 


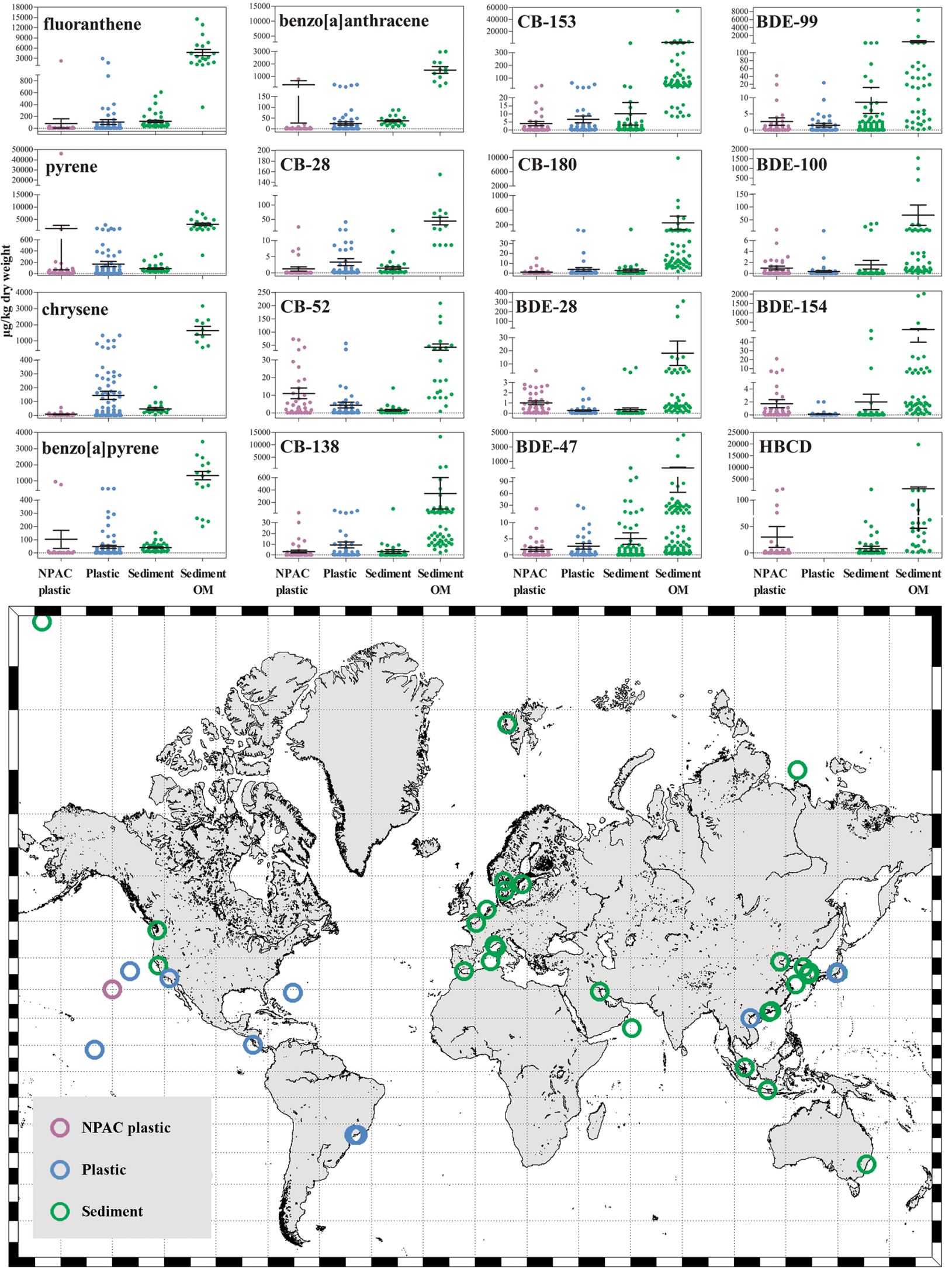

Figure 3. PBT concentrations in ocean plastics from this study ("NPAC plastic"), other studies ("Plastic"), marine sediments ("Sediment"), and organic manner normalized marine sediments ("Sediment OM"). Whiskers represent standard error ranges and middle lines are the mean values for each group. Map displays approximate locations of samples from this study ("NPAC plastic") and other studies ("Plastic", "Sediment"). Plastic data were taken from Fisner et al. $(2013 \mathrm{a}, \mathrm{b}),{ }^{20,28}$ Hirai et al. (2011), ${ }^{2}$ Mato et al. (2001), ${ }^{3}$ and sediment data from Jiao et al. (2009), ${ }^{40} \mathrm{Klamer}$ et al. (2005), ${ }^{41}$ Moon et al. (2007 a, b), ${ }^{46,47}$ Zheng et al. (2004), ${ }^{57}$ Xiang et al. (2007), ${ }^{55}$ Wang et al. (2016), ${ }^{54}$ Al-Odaini et al. (2015), ${ }^{29}$ Lyons et al. (2015), ${ }^{44}$ Zhang et al. (2015), ${ }^{56}$ Li et al. (2014), ${ }^{42}$ Ilyas et al. (2011), ${ }^{39}$ Ramu et al. (2010), ${ }^{52}$ Lipiatou et al. (1993), ${ }^{43}$ Raoux et al. (1999), ${ }^{53}$ Prahl 
Figure 3. continued

and Carpenter (1979), ${ }^{50}$ Palm et al. (2004), ${ }^{49}$ Oros et al. (2005), ${ }^{48}$ Christensen and Platz (2001), ${ }^{33}$ Qiu et al. (2009), ${ }^{51}$ Minh et al. (2007), ${ }^{45}$ Drage et al. (2015), ${ }^{38}$ de Wit et al. (2006), ${ }^{37}$ Dachs et al. $(1996,1999),{ }^{35,36}$ Bouloubassi et al. (2006), ${ }^{31}$ Couderc et al. (2016), ${ }^{34}$ Axelman et al. (2000), and Cailleaud et al. (2007). ${ }^{32}$ Details of these studies can be found in SI Table S1 and Figshare. ${ }^{27}$

which accounted for $51 \%$ of the PCB concentrations variance, was mainly composed of 5-7 Cl congeners (SI Table S7). Moreover, penta- to hepta- chlorinated PCB congeners were predominant in all plastic samples (SI Figure S3). Congener profiles dominated by penta BDEs are also commonly observed in other environmental media such as water and biota ${ }^{79}$ and may be indicative of sorption of PBDEs to plastics from water. Nonetheless, we also observed that the less chlorinated congener CB-52 (PC4), whose molecular weight is far less than penta- to hepta-chlorinated PCBs, was another dominant PCB congener in "hard plastic" samples. For PBDEs, PC1 and PC2 were respectively dominated by higher brominated congeners (penta-, hexa- and hepta-) and lower brominated congeners (tri- and tetra-; SI Table S8 and S9). PBDE additives are typically produced commercially at three different levels of bromination, nominally penta-, octa-, and deca-PBDEs. The deca-PBDE formulation made up $83 \%$ of the global market demand in 2001, followed by penta- $11 \%$ and octa- $6 \%{ }^{74}$

PBT Concentrations in Ocean Plastics and Marine Sediments. PBT concentrations in ocean plastics were similar to those in marine sediments according to nonparametric rank regression, with the exception of three PAHs (fluoranthene, pyrene and benzo[a]pyrene) and BDE-28, whose PBT concentrations in plastics were significantly higher than those in sediments $(p<0.05)$. Nonetheless, results changed drastically when comparing plastic PBT burdens with OMnormalized sediment values: all PBTs then showed significantly higher concentrations in the $\mathrm{OM}$ of sediments $(p<0.05$; Figure 3). The calculated plastic/OM of sediment PBT concentration ratios (between median values) were not constant: $0.001-0.01$ for PAHs, 0.004-0.11 for PCBs, 0.020.29 for PBDEs, and 0.04 for HBCD. Since most PAHs are planar compounds, they bind more strongly to condensed (black) carbon sediments than for instance nonplanar PCBs, PBDEs, and $\mathrm{HBCD},{ }^{80}$ which could explain the relative lower plastic/OM of sediment PBT ratios for PAHs. We also calculated the percentage of ocean plastic and marine sediment samples with chemicals exceeding PEL and TEL values (SI Table S10). Both particle types had similar percentage of samples with chemicals exceeding TEL (0-43\% and 4-60\% for plastic and sediment particles, respectively) and PEL (1-15\% and $0-10 \%$ for plastic and sediment, respectively) thresholds.

Velzeboer et al. (2014) report that amorphous OM is likely to have similar PBT concentrations as polyethylene according to lab sorption experiments. ${ }^{16}$ However, many natural sediments present much higher mineralization degree, compaction, and condensed carbon levels (black carbon). ${ }^{81,82}$ This may lead to higher PBT $K_{\mathrm{OM}}$ values for deeper sediments, when compared to ocean plastics. ${ }^{83,84}$ Nonetheless, it is important to highlight that our plastic $\times$ sediment comparisons should be assessed with caution due to the spatial differences between plastic and sediment sampling, which could have led to higher PBT burdens in sediments. While most of our sediment data were from coastal, potentially more polluted environments, the majority of the information on plastics was from oceanic, relatively pristine environments (see map in Figure 3 and Chen et al. 2017). ${ }^{27}$ In addition, nonequilibrium cannot be ruled out for either plastic or sediment, and PBT concentration gradients can occur over oceanic depth profiles. For example, PBDE concentrations in deep ocean water compartments, where some of the compared sediment samples come from, can be up to 1 order of magnitude higher than at the surface layer where floating plastics occur. ${ }^{85}$ Additionally, many publications on ocean plastic PBTs do not provide concentration values for the individual congeners analyzed, decreasing the number of potential comparisons. We suggest that future studies report all congener concentrations separately, as this would allow refinement of the comparisons described above.

Plastic to Biomass Ratios. We estimated that in NPAC surface waters, the dry mass of buoyant plastics $>0.5 \mathrm{~mm}$ is around 180 times higher than the dry mass of biota $>0.5 \mathrm{~mm}$ (plastic $/$ biomass ratio average $=180.7, \max =448.5, \min =$ 15.0, std $=127.7)$. This finding corroborates with what has already been suggested by a previous study. ${ }^{86}$ Identified biota groups included copepods, marine insect Halobates spp., flying fish, lanternfish, jellyfish, salps, Velella spp., Janthina spp., and eggs. When only considering the $0.5-5 \mathrm{~mm}$ material, we estimated that the dry mass of buoyant microplastics is 40 times higher than that of neustonic plankton (microplastic/plankton ratio average $=39.7, \max =143.0, \min =4.6$, std $=38.3$; see SI Table S11). This microplastic/plankton ratio should be taken with care as some plankton groups are quite fragile and can have their biomasses underestimated by trawl sampling. ${ }^{87}$ Furthermore, NPAC microplastic/plankton ratios would likely decrease if smaller size classes $(<0.5 \mathrm{~mm})$ were taken into account due to the potential removal of microscopic plastics from surface waters ${ }^{88}$ and the dominance of $<0.5 \mathrm{~mm}$ plankton groups in this "microbial ecosystem". ${ }^{99}$ Another important aspect is that due to diurnal vertical migrations of organisms, ${ }^{90}$ these plastic/biomass ratios varied between daytime and nighttime. Plastic/biomass and microplastic/plankton ratio averages were respectively 287.7 ( $\mathrm{std}=107.8, \max =448.5$, $\min =129.2)$ and $73.9(\operatorname{std}=33.4, \max =143.0, \min =42.6)$ during the day, while at night they were $95.1(\mathrm{std}=58.5, \max =$ 213.1, $\min =15.0)$ and $12.4(\operatorname{std}=5.8, \max =20.7, \min =4.6)$.

Potential Implications for Bioaccumulation. The high plastic/biomass ratios within NPAC surface waters indicate that plastic may be a major diet component of NPAC organisms feeding opportunistically upon floating $>0.5 \mathrm{~mm}$ particles. There is some literature data corroborating with this hypothesis. For instance, high amounts of plastic have been reported in the digestive tract of sea turtles by-caught in fisheries operating within and around the NPAC region. ${ }^{91,92}$ The percent composition of ocean plastics (by dry weight) in the digestive contents of sea turtles feeding in these sea surface waters has been shown to be $74 \%$ for loggerheads $(N=2)$, $60.5 \%$ for hawksbills $(N=1), 29 \%$ for greens $(N=22), 14 \%$ for olive ridleys $(N=45)$, and $0 \%$ for leatherbacks $(N=2) .^{91-93}$ Another example is oceanic seabirds. ${ }^{24,94,95}$ For instance, the boluses of Laysan albatross chicks from Kure Atoll and Oahu Island have around $45 \%$ of their wet mass composed of plastics from surfaces waters of the North Pacific subtropical gyre. ${ }^{24}$

It seems that PBTs associated with ingested NPAC plastics could be transferred to predators by fugacity gradient-based 
diffusion. ${ }^{13}$ PBDE congener concentrations in NPAC plastics of the present study were higher than those found in lipids of Yellowtail fish ${ }^{62}$ and Laysan albatross ${ }^{63}$ caught within the North Pacific subtropical gyre by an average of 14 and 23 times, respectively. Furthermore, seven out of the eight PBDE congeners with concentrations measured in both NPAC plastic and Yellowtail fish had plastic/fish-lipid fugacity ratios higher than one (1.7-87.2 times higher; SI Table S12). For the seabirds, ${ }^{63}$ four out of six PBDE congeners had plastic/birdlipid fugacity ratios higher than one (1.3-82.4 times higher; SI Table S13). These positive fugacity ratios indicate possible transfer of plastic-associated chemicals to NPAC predators. There are previous studies suggesting transfer of pollutants from ingested plastic to oceanic predators (e.g., short-tailed shearwaters ${ }^{94,96,97}$ myctophid fish, ${ }^{98}$ and black-footed alba$\operatorname{tross}^{23}$ ), but provided evidence is either limited or problematic. $^{13}$ Therefore, we suggest that future studies better assess the chemical risks of plastic-associated pollutants to organisms inhabiting oligotrophic plastic pollution hotspots such as the NPAC.

\section{ASSOCIATED CONTENT}

\section{S Supporting Information}

. The Supporting Information is available free of charge on the ACS Publications website at DOI: 10.1021/acs.est.7b04682.

Methods description for PBTs extractions and quantification; Information related to the data from the literature used in our ocean plastic $\mathrm{x}$ marine sediment PBTs comparisons (Table S1); Plastic type, size class, dry weight, and PBTs concentrations in samples of this study (Table S2, Table S3, Table S4, Table S5); Principal component analysis of PCB congeners (Table S6); Rotated component matrix after principal component analysis of PCB congeners (Table S7); Principal component analysis of PBDE congeners (Table S8); Rotated component matrix after principal component analysis of PBDE congeners (Table S9); Percentage of ocean plastic and marine sediment samples that exceed threshold effect levels (Table S10); Dry weights of plastic and biomass collected by Manta net tows (Table S11); Estimated fugacity ratios of PBT congeners between plastic and lipids of Yellowtail fish (Table S12); Estimated fugacity ratios of PBT congeners between plastic and lipids of Laysan albatross (Table S13); Polymer composition of ocean plastics of different sizes and types (Figure S1); LPAH/HPAH ratios in ocean plastics (Figure S2); Composition of PCB congeners in the ocean plastic samples of this study (Figure S3) (PDF)

\section{AUTHOR INFORMATION}

\section{Corresponding Author}

*E-mail: jureisser@gmail.com.

\section{ORCID $\odot$}

Julia Reisser: 0000-0002-1785-1042

Albert A. Koelmans: 0000-0001-7176-4356

\section{Notes}

The authors declare no competing financial interest.

\section{ACKNOWLEDGMENTS}

We thank the "Mega Expedition" crew for assistance with sample collection and preparation. This research was funded by The Ocean Cleanup Foundation. Qiqing Chen was supported by the China Postdoctoral Science Foundation Grant during the execution of this study (2015M581657).

\section{REFERENCES}

(1) Eriksen, M.; Lebreton, L. C. M.; Carson, H. S.; Thiel, M.; Moore, C. J.; Borerro, J. C.; Galgani, F.; Ryan, P. G.; Reisser, J. Plastic pollution in the world's oceans: more than 5 trillion plastic pieces weighing over 250,000 tons afloat at sea. PLoS One 2014, 9 (12), e111913.

(2) Hirai, H.; Takada, H.; Ogata, Y.; Yamashita, R.; Mizukawa, K.; Saha, M.; Kwan, C.; Moore, C.; Gray, H.; Laursen, D.; Zettler, E. R; Farrington, J. W.; Reddy, C. M.; Peacock, E. E.; Ward, M. W. Organic micropollutants in marine plastics debris from the open ocean and remote and urban beaches. Mar. Pollut. Bull. 2011, 62 (8), 1683-1692.

(3) Mato, Y.; Isobe, T.; Takada, H.; Kanehiro, H.; Ohtake, C.; Kaminuma, T. Plastic resin pellets as a transport medium for toxic chemicals in the marine environment. Environ. Sci. Technol. 2001, 35 (2), 318-324.

(4) Moore, C. Trashed - across the pacific ocean, plastics, plastics, everywhere. Nat. Hist. 2003, 112 (9), 46-51.

(5) Rios, L. M.; Jones, P. R.; Moore, C.; Narayan, U. V. Quantitation of persistent organic pollutants adsorbed on plastic debris from the Northern Pacific Gyre's "eastern garbage patch". J. Environ. Monit. 2010, 12 (12), 2226-2236.

(6) Teuten, E. L.; Saquing, J. M.; Knappe, D. R. U.; Barlaz, M. A.; Jonsson, S.; Bjorn, A.; Rowland, S. J.; Thompson, R. C.; Galloway, T. S.; Yamashita, R.; Ochi, D.; Watanuki, Y.; Moore, C.; Pham, H. V.; Tana, T. S.; Prudente, M.; Boonyatumanond, R.; Zakaria, M. P.; Akkhavong, K.; Ogata, Y.; Hirai, H.; Iwasa, S.; Mizukawa, K.; Hagino, Y.; Imamura, A.; Saha, M.; Takada, H. Transport and release of chemicals from plastics to the environment and to wildlife. Philos. Trans. R. Soc., B 2009, 364 (1526), 2027-2045.

(7) Endo, S.; Koelmans, A. A. Sorption of Hydrophobic Organic Compounds to Plastics in the Marine Environment: Equilibrium. In Springer Berlin Heidelberg: Berlin, Heidelberg, 2016; pp 1-20.

(8) Lohmann, R. Critical review of low-density polyethylene's partitioning and diffusion coefficients for trace organic contaminants and implications for its use as a passive sampler. Environ. Sci. Technol. 2012, 46 (2), 606-618.

(9) Law, K. L.; Thompson, R. C. Microplastics in the seas. Science 2014, 345 (6193), 144-145.

(10) Gregory, M. R. Environmental implications of plastic debris in marine settings-entanglement, ingestion, smothering, hangers-on, hitch-hiking and alien invasions. Philos. Trans. R. Soc., B 2009, 364 (1526), 2013-2025.

(11) Andrady, A. L. Microplastics in the marine environment. Mar Pollut. Bull. 2011, 62, 1596-1605.

(12) Li, J. N.; Qu, X. Y.; Su, L.; Zhang, W. W.; Yang, D. Q.; Kolandhasamy, P.; Li, D. J.; Shi, H. H. Microplastics in mussels along the coastal waters of China. Environ. Pollut. 2016, 214, 177-184.

(13) Koelmans, A. A.; Bakir, A.; Burton, G. A.; Janssen, C. R. Microplastic as a vector for chemicals in the aquatic environment: critical review and model-supported reinterpretation of empirical studies. Environ. Sci. Technol. 2016, 50 (7), 3315-3326.

(14) Rochman, C. M.; Hoh, E.; Hentschel, B. T.; Kaye, S. Long-term field measurement of sorption of organic contaminants to five types of plastic pellets: implications for plastic marine debris. Environ. Sci. Technol. 2013, 47 (3), 1646-1654.

(15) Beckingham, B.; Ghosh, U. Differential bioavailability of polychlorinated biphenyls associated with environmental particles: microplastic in comparison to wood, coal and biochar. Environ. Pollut. 2017, 220, 150-158. 
(16) Velzeboer, I.; Kwadijk, C. J. A. F.; Koelmans, A. A. Strong sorption of PCBs to nanoplastics, microplastics, carbon nanotubes, and fullerenes. Environ. Sci. Technol. 2014, 48 (9), 4869-4876.

(17) Canadian Sediment Quality Guidelines for the Protection of Aquatic Life, 2001.

(18) Federal Environmental Quality Guidelines Hexabromocyclododecane (HBCD), 2016.

(19) Federal Environmental Quality Guidelines Polybrominated Diphenyl Ethers (PBDEs), 2013.

(20) Fisner, M.; Taniguchi, S.; Moreira, F.; Bicego, M. C.; Turra, A. Polycyclic aromatic hydrocarbons (PAHs) in plastic pellets: variability in the concentration and composition at different sediment depths in a sandy beach. Mar. Pollut. Bull. 2013, 70 (1-2), 219-226.

(21) Maximenko, N.; Hafner, J.; Niiler, P. Pathways of marine debris derived from trajectories of Lagrangian drifters. Mar. Pollut. Bull. 2012, 65 (1-3), 51-62.

(22) Law, K. L.; Moret-Ferguson, S. E.; Goodwin, D. S.; Zettler, E. R.; De Force, E.; Kukulka, T.; Proskurowski, G. Distribution of surface plastic debris in the eastern Pacific Ocean from an 11-year data set. Environ. Sci. Technol. 2014, 48 (9), 4732-4738.

(23) Chu, S. G.; Wang, J.; Leong, G.; Woodward, L. A.; Letcher, R. J.; $\mathrm{Li}, \mathrm{Q}$. X. Perfluoroalkyl sulfonates and carboxylic acids in liver, muscle and adipose tissues of black-footed albatross (Phoebastria nigripes) from Midway Island, North Pacific Ocean. Chemosphere 2015, 138, $60-66$.

(24) Young, L. C.; Vanderlip, C.; Duffy, D. C.; Afanasyev, V.; Shaffer, S. A., Bringing home the trash: do colony-based differences in foraging distribution lead to increased plastic ingestion in Laysan albatrosses? PLoS One 2009, 4, (10).e762310.1371/journal.pone.0007623

(25) MacDonald, D. D.; Ingersoll, C. G.; Berger, T. A. Development and evaluation of consensus-based sediment quality guidelines for freshwater ecosystems. Arch. Environ. Contam. Toxicol. 2000, 39 (1), $20-31$.

(26) Tsanis, I. K.; Xu, P.; Marsalek, J. Estimates of toxic contaminant mean concentrations and loads from runoff water-quality data. J. Great Lakes Res. 1994, 20 (2), 435-442.

(27) Chen, Q.; Reisser, J.; Cunsolo, S.; Kwadijk, C.; Kotterman, M.; Proietti, M.; Slat, B.; Ferrari, F. F.; Schwarz, A.; Levivier, A.; Yin, D. Q.; Hollert, H.; Koelmans, A. A., Data from 'Pollutants in Plastics within the North Pacific Subtropical Gyre'. Figshare 2017, https://doi.org/10. 6084/m9.figshare.5632264.

(28) Fisner, M.; Taniguchi, S.; Majer, A. P.; Bicego, M. C.; Turra, A. Concentration and composition of polycyclic aromatic hydrocarbons (PAHs) in plastic pellets: Implications for small-scale diagnostic and environmental monitoring. Mar. Pollut. Bull. 2013, 76 (1-2), 349354.

(29) Al-Odaini, N. A.; Shim, W. J.; Han, G. M.; Jang, M.; Hong, S. H. Enrichment of hexabromocyclododecanes in coastal sediments near aquaculture areas and a wastewater treatment plant in a semi-enclosed bay in South Korea. Sci. Total Environ. 2015, 505, 290-298.

(30) Axelman, J.; Broman, D.; Naf, C. Vertical flux and particulate/ water dynamics of polychlorinated biphenyls (PCBs) in the open Baltic Sea. Ambio 2000, 29 (4-5), 210-216.

(31) Bouloubassi, I.; Mejanelle, L.; Pete, R.; Fillaux, J.; Lorre, A.; Point, V. PAH transport by sinking particles in the open Mediterranean Sea: A 1 year sediment trap study. Mar. Pollut. Bull. 2006, 52 (5), 560-571.

(32) Cailleaud, K.; Forget-Leray, J.; Souissi, S.; Hilde, D.; LeMenach, K.; Budzinski, H. Seasonal variations of hydrophobic organic contaminant concentrations in the water-column of the Seine Estuary and their transfer to a planktonic species Eurytemora affinis (Calanoida, copepoda). Part 1: PCBs and PAHs. Chemosphere 2007, 70 (2), 270-280.

(33) Christensen, J. H.; Platz, J. Screening of polybrominated diphenyl ethers in blue mussels, marine and freshwater sediments in Denmark. J. Environ. Monit. 2001, 3 (5), 543-547.

(34) Couderc, M.; Gandolfi, F.; Zalouk-Vergnoux, A.; Beyeler, N.; Malleret, L.; Ambidina, I.; Kamari, A.; Blanchet-Letrouve, I.; Mouneyrac, C.; Hamers, T.; Poirier, L. Levels and distributions of organic pollutants in subtidal sediments from the: Loire estuary: are there any relationships with TTR-binding activity? J. Sea Res. 2016, $118,59-68$

(35) Dachs, J.; Bayona, J. M.; Fowler, S. W.; Miquel, J. C.; Albaiges, J. Vertical fluxes of polycyclic aromatic hydrocarbons and organochlorine compounds in the western Alboran Sea (southwestern Mediterranean). Mar. Chem. 1996, 52 (1), 75-86.

(36) Dachs, J.; Bayona, J. M.; Ittekkot, V.; Albaiges, J. Monsoondriven vertical fluxes of organic pollutants in the western Arabian Sea. Environ. Sci. Technol. 1999, 33 (22), 3949-3956.

(37) de Wit, C. A.; Alaee, M.; Muir, D. C. G. Levels and trends of brominated flame retardants in the Arctic. Chemosphere 2006, 64 (2), 209-233.

(38) Drage, D.; Mueller, J. F.; Birch, G.; Eaglesham, G.; Hearn, L. K.; Harrad, S. Historical trends of PBDEs and HBCDs in sediment cores from Sydney estuary, Australia. Sci. Total Environ. 2015, 512, 177-184.

(39) Ilyas, M.; Sudaryanto, A.; Setiawan, I. E.; Riyadi, A. S.; Isobe, T.; Takahashi, S.; Tanabe, S. Characterization of polychlorinated biphenyls and brominated flame retardants in sediments from riverine and coastal waters of Surabaya, Indonesia. Mar. Pollut. Bull. 2011, 62 (1), 89-98.

(40) Jiao, L. P.; Zheng, G. J.; Minh, T. B.; Richardson, B.; Chen, L. Q.; Zhang, Y. H.; Yeung, L. W.; Lam, J. C. W.; Yang, X. L.; Lam, P. K. S.; Wong, M. H. Persistent toxic substances in remote lake and coastal sediments from Svalbard, Norwegian Arctic: levels, sources and fluxes. Environ. Pollut. 2009, 157 (4), 1342-1351.

(41) Klamer, H. J. C.; Leonards, P. E. G.; Lamoree, M. H.; Villerius, L. A.; Akerman, J. E.; Bakker, J. F. A chemical and toxicological profile of Dutch North Sea surface sediments. Chemosphere 2005, 58 (11), $1579-1587$.

(42) Li, X. M.; Gao, Y.; Wang, Y. W.; Pan, Y. Y. Emerging persistent organic pollutants in Chinese Bohai Sea and its coastal regions. Sci. World J. 2014, 2014, 608231.

(43) Lipiatou, E.; Marty, J. C.; Saliot, A. Sediment trap fluxes of polycyclic aromatic-hydrocarbons in the Mediterranean-Sea. Mar. Chem. 1993, 44 (1), 43-54.

(44) Lyons, B. P.; Barber, J. L.; Rumney, H. S.; Bolam, T. P. C.; Bersuder, P.; Law, R. J.; Mason, C.; Smith, A. J.; Morris, S.; Devlin, M. J.; Al-Enezi, M.; Massoud, M. S.; Al-Zaidan, A. S.; Al-Sarawi, H. A. Baseline survey of marine sediments collected from the State of Kuwait: PAFIs, PCBs, brominated flame retardants and metal contamination. Mar. Pollut. Bull. 2015, 100 (2), 629-636.

(45) Minh, N. H.; Isobe, T.; Ueno, D.; Matsumoto, K.; Mine, M.; Kajiwara, N.; Takahashi, S.; Tanabe, S. Spatial distribution and vertical profile of polybrominated diphenyl ethers and hexabromocyclododecanes in sediment core from Tokyo Bay, Japan. Environ. Pollut. 2007, 148 (2), 409-417.

(46) Moon, H. B.; Kannan, K.; Choi, M.; Choi, H. G. Polybrominated diphenyl ethers (PBDEs) in marine sediments from industrialized bays of Korea. Mar. Pollut. Bull. 2007, 54 (9), 14021412.

(47) Moon, H. B.; Kannan, K.; Lee, S. J.; Choi, M. Polybrominated diphenyl ethers (PBDEs) in sediment and bivalves from Korean coastal waters. Chemosphere 2007, 66 (2), 243-251.

(48) Oros, D. R.; Hoover, D.; Rodigari, F.; Crane, D.; Sericano, J. Levels and distribution of polybrominated diphenyl ethers in water, surface sediments, and bivalves from the San Francisco Estuary. Environ. Sci. Technol. 2005, 39 (1), 33-41.

(49) Palm, A.; Cousins, I.; Gustafsson, O.; Axelman, J.; Grunder, K.; Broman, D.; Brorstrom-Lunden, E. Evaluation of sequentially-coupled POP fluxes estimated from simultaneous measurements in multiple compartments of an air-water-sediment system. Environ. Pollut. 2004, $128(1-2), 85-97$.

(50) Prahl, F. G.; Carpenter, R. Role of zooplankton fecal pellets in the sedimentation of polycyclic aromatic-hydrocarbons in Dabob Bay, Washington. Geochim. Cosmochim. Acta 1979, 43 (12), 1959-1972.

(51) Qiu, Y. W.; Zhang, G.; Liu, G. Q.; Guo, L. L.; Li, X. D.; Wai, O. Polycyclic aromatic hydrocarbons (PAHs) in the water column and 
sediment core of Deep Bay, South China. Estuarine, Coastal Shelf Sci. 2009, 83 (1), 60-66.

(52) Ramu, K.; Isobe, T.; Takahashi, S.; Kim, E. Y.; Min, B. Y.; We, S. U.; Tanabe, S. Spatial distribution of polybrominated diphenyl ethers and hexabromocyclododecanes in sediments from coastal waters of Korea. Chemosphere 2010, 79 (7), 713-719.

(53) Raoux, C.; Bayona, J. M.; Miquel, J. C.; Teyssie, J. L.; Fowler, S. W.; Albaiges, J. Particulate fluxes of aliphatic and aromatic hydrocarbons in near-shore waters to the northwestern Mediterranean Sea, and the effect of continental runoff. Estuarine, Coastal Shelf Sci. 1999, 48 (5), 605-616.

(54) Wang, G. G.; Peng, J. L.; Xu, X.; Zhang, D. H.; Li, X. G. Polybrominated diphenyl ethers in sediments from the Southern Yellow Sea: concentration, composition profile, source identification and mass inventory. Chemosphere 2016, 144, 2097-2105.

(55) Xiang, C. H.; Luo, X. J.; Chen, S. J.; Yu, M.; Mai, B. X.; Zeng, E. Y. Polybrominated diphenyl ethers in biota and sediments of the Pearl River Estuary, South China. Environ. Toxicol. Chem. 2007, 26 (4), 616-623.

(56) Zhang, H.; Bayen, S.; Kelly, B. C. Co-extraction and simultaneous determination of multi-class hydrophobic organic contaminants in marine sediments and biota using GC-EI-MS/MS and LC-ESI-MS/MS. Talanta 2015, 143, 7-18.

(57) Zheng, G. J.; Martin, M.; Richardson, B. J.; Yu, H. X.; Liu, Y.; Zhou, C. H.; Li, J.; Hu, G. J.; Lain, M. H. W.; Lam, P. K. S. Concentrations of polybrominated diphenyl ethers (PBDEs) in Pearl River Delta sediments. Mar. Pollut. Bull. 2004, 49 (5-6), 520-524.

(58) Herzke, D.; Anker-Nilssen, T.; Nost, T. H.; Gotsch, A.; Christensen-Dalsgaard, S.; Langset, M.; Fangel, K.; Koelmans, A. A. Negligible impact of ingested microplastics on tissue concentrations of persistent organic pollutants in northern Fulmars off coastal Norway. Environ. Sci. Technol. 2016, 50 (4), 1924-1933.

(59) Besseling, E.; Foekema, E. M.; van den Heuvel-Greve, M. J.; Koelmans, A. A. The effect of microplastic on the uptake of chemicals by the lugworm Arenicola marina (L.) under environmentally relevant exposure conditions. Environ. Sci. Technol. 2017, 51 (15), 8795-8804.

(60) Griffiths, D. Prey availability and the food of predators. Ecology 1975, 56 (5), 1209-1214.

(61) Gulka, J.; Carvalho, P. C.; Jenkins, E.; Johnson, K.; Maynard, L.; Davoren, G. K., Dietary niche shifts of multiple marine predators under varying prey availability on the northeast newfoundland coast. Front. Mar. Sci. 2017, 4, (324).10.3389/fmars.2017.00324

(62) Gassel, M.; Harwani, S.; Park, J. S.; Jahn, A. Detection of nonylphenol and persistent organic pollutants in fish from the North Pacific Central Gyre. Mar. Pollut. Bull. 2013, 73 (1), 231-242.

(63) Kunisue, T.; Higaki, Y.; Isobe, T.; Takahashi, S.; Subramanian, A.; Tanabe, S. Spatial trends of polybrominated diphenyl ethers in avian species: utilization of stored samples in the Environmental Specimen Bank of Ehime University (es-Bank). Environ. Pollut. 2008, 154 (2), 272-282.

(64) Moret-Ferguson, S.; Law, K. L.; Proskurowski, G.; Murphy, E. K.; Peacock, E. E.; Reddy, C. M. The size, mass, and composition of plastic debris in the western North Atlantic Ocean. Mar. Pollut. Bull. 2010, 60 (10), 1873-1878.

(65) Karapanagioti, H. K.; Klontza, I. Testing phenanthrene distribution properties of virgin plastic pellets and plastic eroded pellets found on Lesvos island beaches (Greece). Mar. Environ. Res. 2008, 65 (4), 283-290.

(66) Endo, S.; Takizawa, R; Okuda, K.; Takada, H.; Chiba, K.; Kanehiro, H.; Ogi, H.; Yamashita, R.; Date, T. Concentration of polychlorinated biphenyls (PCBs) in beached resin pellets: variability among individual particles and regional differences. Mar. Pollut. Bull. 2005, 50 (10), 1103-1114.

(67) Lee, H.; Shim, W. J.; Kwon, J. H. Sorption capacity of plastic debris for hydrophobic organic chemicals. Sci. Total Environ. 2014, 470, 1545-1552.

(68) Teuten, E. L.; Rowland, S. J.; Galloway, T. S.; Thompson, R. C. Potential for plastics to transport hydrophobic contaminants. Environ. Sci. Technol. 2007, 41 (22), 7759-7764.
(69) Leggett, D. C.; Parker, L. V. Modeling the equilibrium partitioning of organic contaminants between PTFE, PVC, and groundwater. Environ. Sci. Technol. 1994, 28 (7), 1229-1233.

(70) Nguyen, T. H.; Goss, K. U.; Ball, W. P. Polyparameter linear free energy relationships for estimating the equilibrium partition of organic compounds between water and the natural organic matter in soils and sediments. Environ. Sci. Technol. 2005, 39 (4), 913-924.

(71) Hansen, E.; Nilsson, N.; Lithner, D.; Lassen, C., Hazardous substances in plastic materials. In Hazardous Substances in Plastic Materials; Danish Technological Institute, 2013; pp 84-86.

(72) Jang, M.; Shim, W. J.; Han, G. M.; Rani, M.; Song, Y. K.; Hong, S. H. Styrofoam debris as a source of hazardous additives for marine organisms. Environ. Sci. Technol. 2016, 50 (10), 4951-4960.

(73) Rani, M.; Shim, W. J.; Han, G. M.; Jang, M.; Song, Y. K.; Hong, S. H. Hexabromocyclododecane in polystyrene based consumer products: an evidence of unregulated use. Chemosphere 2014, 110, $111-119$.

(74) La Guardia, M. J.; Hale, R. C.; Harvey, E. Detailed polybrominated diphenyl ether (PBDE) congener composition of the widely used penta-, octa-, and deca-PBDE technical flameretardant mixtures. Environ. Sci. Technol. 2006, 40 (20), 6247-6254.

(75) Robertson, L. W.; Hansen, L. G. PCBs: Recent Advances in Environmental Toxicology and Health Effects; University Press of Kentucky: Lexington, KY, 2001; p 461.

(76) Heskett, M.; Takada, H.; Yamashita, R.; Yuyama, M.; Ito, M.; Geok, Y. B.; Ogata, Y.; Kwan, C.; Heckhausen, A.; Taylor, H.; Powell, T.; Morishige, C.; Young, D.; Patterson, H.; Robertson, B.; Bailey, E.; Mermoz, J. Measurement of persistent organic pollutants (POPs) in plastic resin pellets from remote islands: toward establishment of background concentrations for International Pellet Watch. Mar. Pollut. Bull. 2012, 64 (2), 445-448.

(77) Ogata, Y.; Takada, H.; Mizukawa, K.; Hirai, H.; Iwasa, S.; Endo, S.; Mato, Y.; Saha, M.; Okuda, K.; Nakashima, A.; Murakami, M.; Zurcher, N.; Booyatumanondo, R.; Zakaria, M. P.; Dung, L. Q.; Gordon, M.; Miguez, C.; Suzuki, S.; Moore, C.; Karapanagioti, H. K.; Weerts, S.; McClurg, T.; Burres, E.; Smith, W.; Van Velkenburg, M.; Lang, J. S.; Lang, R. C.; Laursen, D.; Danner, B.; Stewardson, N.; Thompson, R. C. International pellet watch: global monitoring of persistent organic pollutants (POPs) in coastal waters. 1. Initial phase data on PCBs, DDTs, and HCHs. Mar. Pollut. Bull. 2009, 58 (10), 1437-1446.

(78) Stogiannidis, E.; Laane, R. Source characterization of polycyclic aromatic hydrocarbons by using their molecular indices: an overview of possibilities. Rev. Environ. Contam. Toxicol. 2015, 234, 49-133.

(79) Mizukawa, K.; Takada, H.; Takeuchi, I.; Ikemoto, T.; Omori, K.; Tsuchiya, K. Bioconcentration and biomagnification of polybrominated diphenyl ethers (PBDEs) through lower-trophic-level coastal marine food web. Mar. Pollut. Bull. 2009, 58 (8), 1217-1224.

(80) Cornelissen, G.; Gustafsson, O. Prediction of large variation in biota to sediment accumulation factors due to concentrationdependent black carbon adsorption of planar hydrophobic organic compounds. Environ. Toxicol. Chem. 2005, 24 (3), 495-498.

(81) Koelmans, A. A.; Jonker, M. T. O.; Cornelissen, G.; Bucheli, T. D.; Van Noort, P. C. M.; Gustafsson, O. Black carbon: the reverse of its dark side. Chemosphere 2006, 63 (3), 365-377.

(82) Koelmans, A. A.; Gillissen, F.; Makatita, W.; VandenBerg, M. Organic carbon normalisation of PCB, PAH and pesticide concentrations in suspended solids. Water Res. 1997, 31 (3), 461-470.

(83) Hauck, M.; Huijbregts, M. A. J.; Koelmans, A. A.; Moermond, C. T. A.; van den Heuvel-Greve, M. J.; Veltman, K.; Hendriks, A. J.; Vethaak, A. D. Including sorption to black carbon in modeling bioaccumulation of polycyclic aromatic hydrocarbons: uncertainty analysis and comparison to field data. Environ. Sci. Technol. 2007, 41 (8), 2738-2744.

(84) Prevedouros, K.; Palm-Cousins, A.; Gustafsson, O.; Cousins, I. T. Development of a black carbon-inclusive multi-media model: application for PAHs in Stockholm. Chemosphere 2008, 70 (4), 607615 . 
(85) Salvado, J. A.; Sobek, A.; Carrizo, D.; Gustafsson, O. Observation-based assessment of PBDE loads in Arctic Ocean waters. Environ. Sci. Technol. 2016, 50 (5), 2236-2245.

(86) Moore, C. J.; Moore, S. L.; Leecaster, M. K.; Weisberg, S. B. A comparison of plastic and plankton in the North Pacific central gyre. Mar. Pollut. Bull. 2001, 42 (12), 1297-1300.

(87) Biard, T.; Stemmann, L.; Picheral, M.; Mayot, N.; Vandromme, P.; Hauss, H.; Gorsky, G.; Guidi, L.; Kiko, R.; Not, F. In situ imaging reveals the biomass of giant protists in the global ocean. Nature 2016, 532 (7600), 504-507.

(88) Cozar, A.; Echevarria, F.; Gonzalez-Gordillo, J. I.; Irigoien, X.; Ubeda, B.; Hernandez-Leon, S.; Palma, A. T.; Navarro, S.; Garcia-deLomas, J.; Ruiz, A.; Fernandez-de-Puelles, M. L.; Duarte, C. M. Plastic debris in the open ocean. Proc. Natl. Acad. Sci. U. S. A. 2014, 111 (28), 10239-10244.

(89) Karl, D. M. A sea of change: Biogeochemical variability in the North Pacific Subtropical Gyre. Ecosystems 1999, 2 (3), 181-214.

(90) Brierley, A. S. Diel vertical migration. Curr. Biol. 2014, 24 (22), R1074-R1076.

(91) Wedemeyer-Strombel, K. R.; Balazs, G. H.; Johnson, J. B.; Peterson, T. D.; Wicksten, M. K.; Plotkin, P. T. High frequency of occurrence of anthropogenic debris ingestion by sea turtles in the North Pacific Ocean. Mar. Biol. 2015, 162 (10), 2079-2091.

(92) Clukey, K. E.; Lepczyk, C. A.; Balazs, G. H.; Work, T. M.; Lynch, J. M. Investigation of plastic debris ingestion by four species of sea turtles collected as bycatch in pelagic Pacific longline fisheries. Mar. Pollut. Bull. 2017, 120 (1-2), 117-125.

(93) Van Houtan, K. S.; Francke, D. L.; Alessi, S.; Jones, T. T.; Martin, S. L.; Kurpita, L.; King, C. S.; Baird, R. W. The developmental biogeography of hawksbill sea turtles in the North Pacific. Ecol. Evol. 2016, 6 (8), 2378-2389.

(94) Tanaka, K.; Takada, H.; Yamashita, R.; Mizukawa, K.; Fukuwaka, M.; Watanuki, Y. Facilitated leaching of additive-derived PBDEs from plastic by seabirds' stomach oil and accumulation in tissues. Environ. Sci. Technol. 2015, 49 (19), 11799-11807.

(95) Robards, M. D.; Gould, P. J.; Piatt, J. F. The Highest Global Concentrations and Increased Abundance of Oceanic Plastic Debris in the North Pacific: Evidence from Seabirds; Springer: New York, 1997; p 7180.

(96) Yamashita, R.; Takada, H.; Fukuwaka, M. A.; Watanuki, Y. Physical and chemical effects of ingested plastic debris on short-tailed shearwaters, Puffinus tenuirostris, in the North Pacific Ocean. Mar. Pollut. Bull. 2011, 62 (12), 2845-2849.

(97) Tanaka, K.; Takada, H.; Yamashita, R.; Mizukawa, K.; Fukuwaka, M.; Watanuki, Y. Accumulation of plastic-derived chemicals in tissues of seabirds ingesting marine plastics. Mar. Pollut. Bull. 2013, 69 (1-2), 219-222.

(98) Rochman, C. M.; Lewison, R. L.; Eriksen, M.; Allen, H.; Cook, A. M.; Teh, S. J. Polybrominated diphenyl ethers (PBDEs) in fish tissue may be an indicator of plastic contamination in marine habitats. Sci. Total Environ. 2014, 476, 622-633.

(99) A Handbook for Determining the Sources of PCB Contamination in Sediments; U.S. Department of Defense: 2012; p 289. 